\title{
Optimum inclusion level of cotton seed meal as a source of protein in the diets of Nile tilapia, Oreochromis niloticus diet.
}

\author{
Soltan, M.A. ${ }^{1}$, El-sayed, A.I. ${ }^{1}$ Iraqi, M.M' $^{1}$ Goda $^{2}$, A.M. Hassaan${ }^{2}$, M.S. and Ramadan ${ }^{1}$, H. A \\ Fac. Agric. Moshtohor, Benha University, Egypt ${ }^{1}$ \\ National institute of Oceanography and fisheries (NIOF), Cairo, Egypt ${ }^{2}$ \\ Corresponding author: magdy.soltan@fagr.bu.edu.eg
}

\begin{abstract}
The present study was designed to investigate the effect of incorporation of cotton seed meal CSM in the diets of Nile tilapia Oreochromis niloticus. A set of 108 fish of $O$. niloticus L. mono-sex male fingerlings with average initial weight of $11.60 \pm 0.72 \mathrm{~g}$ was used in this trail. Twelve fish were randomly stocked into each aquarium with three replications for each treatment and fed the experimental diet (295 $\mathrm{g} \mathrm{kg}^{-1}$ crude protein) and isocaloric (18.76 $\mathrm{MJ} \mathrm{kg}^{-1}$ gross energy). The first diet CSM1 which contained (fish meal : cotton seed meal 2:1), the second CSM2 which contained (fish meal : cotton seed meal 2:2) and the third CSM3 which contained (fish meal : cotton seed meal 1:2). Results of the present experiment indicated that, inclusion of cotton seed meal CSM had slightly significant effect on final body weight BW between groups CSM1(FM: CSM; 2:1) and CSM2 (FM:CSM; 2:2), but had no significantly effect on final BW between groups CSM1(FM: CSM; 2:1) and CSM2 (FM:CSM; 2:2). Weight gain (WG) and specific growth rate (SGR) were significantly higher in fish fed diet containing (FM: CSM 2:1) ratio, but no significant differences in WG, SGR and survival rate (SR) values of groups received the ratios of FM: CSM (2:2 and 1:2). The best feed conversion ratio (FCR), and protein productive value (PPV) were obtained by fish fed containing (FM: CSM= 2:1) followed by (FM: CSM= 2:1). There were no significant differences in protein efficiency ratio (PER). The highest apparent digestibility dry matter (DM) was obtained from fish fed diet containing (FM: $C S M=2: 1)$ followed by $(F M: C S M=2: 1)$, with significant $(\mathrm{P}>0.005)$ differences between $F M$ : $\mathrm{CSM}=2: 1$ and 2:2 ratio. The opposite trend was observed in apparent digestibility of protein. Meanwhile, there was no significant differences in apparent digestibility of lipid and energy.
\end{abstract}

Key words: cotton seed meal, fish meal, tilapia diets, growth and feed utilization

\section{Introduction}

The global aquaculture industry contributed $42.2 \%$ to world food fish production in 2012 and accounted for half of the world's fish for direct consumption (FAO, 2014). To maintain its current average growth rate of 8 to 10 percent per year up to 2025 , the supply of nutrient and feed inputs will have to grow at a similar rate which is a tuff task (Tacon et al., 2011). In fact success of aquaculture, a reliable source of economic gain and employment generation, mainly stands on the cost of formulated fish feed which is the largest production cost for commercial aquaculture. Thus, improving feed efficiency in industrial systems is already a priority (Naylor et al., 2000). In aquaculture production, fishmeal (FM) typically is regarded as the main protein source in formulated diets due to its high level of protein, excellent amino acid profile, low carbohydrate level and high digestibility (Zhou et al., 2004). The FM prices have risen continuously in real terms in the past decades and are likely to increase further with continued growth in demand (FAO, 2010). As a result, restricted FM supplies can no longer meet the needs of the expanding fish-feed industry (Bostock et al., 2010). Moreover, the use of animal protein for feeding herbivorous fish might be unnecessary. Therefore, replacements for FM have an international research priority (Kumar et al., 2010) and to bring down the feed cost and to develop low cost and high yield production system (Cho et al., 1994).

In view of the increasing cost of ingredients for aquafeeds, the search for cheap and nutritionally balanced ingredients as well as available for fish feed has become an urgent need for the aquaculture industry. Especially, the evaluation of the nutritional value and potential of locally available nutrient sources is an important aspect for the substitution of conventional fish feed ingredients. Plant proteins might be considered as the most viable alternative in this respect for economic fish production in most of the developing countries (Becker and Makkar, 1999). Several studies in recent past to make supplementary feeding of fish cost-effective have been directed to substitute the high cost fish meal with less expensive protein sources. This aspect of feed development research is centered on the search for inexpensive, readily available and nutritious protein sources that can supply all the nutritional needs of the fish.

Cottonseed meal (CSM), a high protein byproduct of the cottonseed processing industry, has been studied in numerous fish species, Sarotherodon mossambicus (Jackson et al., 1982) and Oreochromis niloticus (Yue and Zhou 2008; Soltan et al., 2011a\&b), Ictalurus punctatus (Robinson and 
Tiersch 1995), and Oncorhynchus mykiss (Lee et al., 2006). These studies showed positive results at low inclusion levels, but growth reduction at high inclusion levels. Among the factors which limit incorporation of these ingredients into aquafeeds are (1) amino-acid imbalance and presence of antinutritional factors such as gossypol (Li and Robinson 2006). In general, oilseed meals processed in traditional ways cannot be utilized at high levels without compromising growth and production. Enhancement of the nutritive value of these ingredients by processing to increase the bioavailability of nutrients, reduce or remove antinutritional factors and the inclusion of appropriate additives could result in oilseed meals being incorporated at higher levels in fish feeds (Wee 1991). Therefore, the present study examined the possibility of utilizing the optimum CSM, as source of protein for Nile tilapia.

\section{Materials and Methods}

\section{Experimental diets}

Three isonitrogenous (295 $\mathrm{g} \mathrm{kg}^{-1}$ crude protein) and isocaloric (18.76 $\mathrm{MJ} \mathrm{kg}^{-1}$ gross energy) experimental diets were formulated and the proximate chemical composition of these experimental diets are presented in Table (1). The first diet CSM1 which contained (fish meal : cotton seed meal 2:1), the second CSM2 which contained (fish meal protein : cotton seed meal prtein 2:2) and the third CSM3 which contained (fish meal protein : cotton seed meal protein 1:2). All dry ingredients of the fish meal, cotton seed meal, soybean meal, yellow corn and wheat bran were blended for 5 mins and thoroughly mixed with soybean oil. Also, each of the diet contained $5 \mathrm{~g} \mathrm{~kg}^{-1}$ chromic oxide $\left(\mathrm{Cr}_{2} \mathrm{O}_{3}\right)$ as a marker for nutrient digestibility measurements. The ingredients were mixed well and made into dry pellets using a laboratory pellet mill (California Pellet Mill, San Francisco, CA, USA). The pellets (2$\mathrm{mm}$ die) were dried for $4 \mathrm{~h}$ at $60^{\circ} \mathrm{C}$ and stored at -20 ${ }^{\circ} \mathrm{C}$ until use.

\section{Experimental fish and culture technique}

$O$. niloticus were obtained from private farm (Kafer elsheekh Governorate, Egypt). Fish were acclimated to the experimental conditions for two weeks at the laboratory of fish at Faculty of Agriculture, Benha Univ. During the acclimation period, fish were fed a control diet $(30 \%$ crude protein) at a rate of $3 \%$ of biomass, which provided of equal rations at 09:00 am and 3:00 pm for 2 weeks to adapt the artificial diet and conditions of the trail.

After the acclimatization, the experimental fish were distributed randomly into glass aquaria $(40 \times 30 \times 60 \mathrm{~cm}$ for each) representing the three treatments studied. A set of 108 fish of $O$. niloticus L. mono-sex male fingerlings average initial weight of $11.60 \pm 0.0 .72 \mathrm{~g}$ was used in this trail. Twelve fish were randomly stocked into each aquarium with three replications for each treatment. De-chlorinated public utility water was supplied to each aquarium housed within an artificially illuminated room. About one-third of water volume in each tank was daily replaced by aerated fresh water after removing the accumulated excreta. During the 90-days experimental period, triplicate groups of tilapia were hand-fed with the respective diet to apparent satiation twice daily at 09:00 am and 3:00 pm.

\section{Water quality}

Water temperature was recorded daily at 13.00 pm using a mercury thermometer. Dissolved oxygen (DO) was measured at 07.00 am using YSI model 56 oxygen meter (YSI Company, Yellow Springs Instrument, Yellow Springs, Ohio, USA). Total ammonia was measured twice weekly using a DREL, 2000 spectrophotometer (Hash Company, Loveland, $\mathrm{CO}$, USA). A pH was measured in morning by using a $\mathrm{pH}$ meter (Orion $\mathrm{pH}$ meter, Abilene, Texas, USA). All tested water quality criteria (temperature, $\mathrm{pH}$ value, DO and total ammonia) were suitable and within the acceptable limits for rearing Nile tilapia $O$. niloticus fingerlings (Boyd, 1990). After two-months from the experiment start, feces were collected from each pond once daily every morning prior to feeding for a one-month period. The feces were collected on filter paper for drying as described by (El-Saidy and Gaber 2002). Apparent nutrient digestibility was calculated using the equations of (Schneider et al., 2004) as following: ADC dietary nutrient $=1$ - $(($ marker diet $) /\left(\right.$ marker $\left._{\text {feces }}\right) \times\left(\right.$ nutrient $\left._{\text {feces }}\right) /\left(\right.$ nutrient $\left.\left._{\text {diet }}\right)\right)$.

\section{Growth performance and feed utilization Indices}

Records of live body weight $(\mathrm{g})$ and body length $(\mathrm{cm})$ of fish were measured in all fish for each tank and registered every 14 days during the experimental period. Growth performance and feed utilization were measured by using the following equations:

Condition factor $(\mathrm{K})=\left(\mathrm{W} / \mathrm{L}^{3}\right) \times 100$; where: $\mathrm{W}=$ weight of fish in grams and $\mathrm{L}=$ total length of fish in "cm"

Weight gain $(\mathrm{WG})=$ final weight $(\mathrm{g})$ - initial weight $(\mathrm{g})$; Specific growth rate $(\mathrm{SGR})=\frac{\mathrm{LnW} 2-\mathrm{LnW} 1}{\mathrm{t}} \times 100$

Where: $\mathrm{Ln}=$ the natural $\log ; \mathrm{W}_{1}=$ first fish weight; $\mathrm{W}_{2}=$ the following fish weight in grams and $t=$ period in days.

Feed conversion ratio $(\mathrm{FCR})=$ Feed intake $(\mathrm{g}) /$ Weight gain $(\mathrm{g})$;

Protein efficiency ratio $(\mathrm{PER})=$ Weight gain $(\mathrm{g}) /$ Protein ingested (g);

Protein productive value $(\mathrm{PPV}) \%=($ protein gain $(\mathrm{g})$ $/$ protein intake $(\mathrm{g})) \times 100$.

\section{Proximate composition}

At the initiation and termination of the trail a random sample of five individual fish were sampled from each aquarium, then oven-dried $105^{\circ} \mathrm{C}$ for $24 \mathrm{~h}$, 
ground, and stored at $-20{ }^{\circ} \mathrm{C}$ for subsequent analysis. At the end of each experiment, two fish were randomly sampled from each aquarium and subjected to the chemical analysis of whole fish body. Moisture, dry matter (DM), ether extract (EE), crude protein $(\mathrm{CP})$, crude fiber $(\mathrm{CF})$ and ash content of diets and fish were determined according to the methods described in AOAC (1995): dry matter after drying in an oven at $105^{\circ} \mathrm{C}$ until constant weight; ash content by incineration in a muffle furnace at $600^{\circ} \mathrm{C}$ for $12 \mathrm{hrs}$; crude protein $(\mathrm{N} \times 6.25)$ by the kjeldhal method after acid digestion; and ether extract by petroleum ether $\left(60-80^{\circ} \mathrm{C}\right)$ extraction.

\section{Statistical analysis}

Statistical analysis of the obtained data was analyzed according to SAS (1996). Differences between means were tested for significance according to Duncan's multiple rang test as described by Duncan (1955).

\section{Results}

\section{Growth performance}

Results presented in Table (2) showed that the differences in fish initial body weight among different treatments were insignificant indicating that the experimental groups at the start of the experiment were randomly distributed. The data cleared that inclusion of cotton seed meal CSM had slightly significant effect on final BW between groups CSM1(FM: CSM; 2:1) and CSM2 (FM:CSM; 2:2). Similar results were obtained in body length except between groups CSM2 (FM: CSM 2:2) and CSM3 (FM:CSM 1:2) which showed insignificant differences. Condition factor $(\mathrm{K})$ factor increased from 1.78 to 2.57 and 2.75 respectively, with significant differences between $\mathrm{K}$ values (Table 2).

Results of Table 3 showed that the different ratios of FM: CSM had significantly effect on WG, SGR and SR for tilapia. The value of WG and SGR were higher in fish fed diet containing (FM: CSM 2:1) ratio, but no significant differences $(\mathrm{P}<0.05)$ in $\mathrm{WG}$, SGR and SR values of groups received ratios of FM: CSM (2:2 and 1:2).

\section{Feed intake and feed utilization}

Results of feed intake (FI), feed conversion ratio (FCR), protein efficacy ratio (PER) and protein productive value (PPV) as affected by FM: CSM ratios are presented in (Table, 4). As described in this table, feed intake during the whole period of the experiment was 41.42, 39.93 and 39.82 for fish groups fed diet containing different ratios of FM: CSM respectively, with insignificant $(\mathrm{P}>0.005)$ differences between these means. The best FCR and PPV was obtained by fish fed containing (FM:CSM= $2: 1$ ) followed by (FM:CSM= 2:2). There was no significant differences in PER.

\section{Digestibility}

Results of apparent digestibility as affected by different ratios of FM: CSM are presented in Table 5. As described in this table, the highest DM was obtained from fish fed diet containing (FM:CSM = 1:2) followed by (FM:CSM= 2:2), with significant (P>0.005) differences between FM: CSM $=2: 1$ and each of 2:2 and 1:2 ratio. The opposite trend was observed in protein. Meanwhile, there was no significant differences $(\mathrm{P}>0.05)$ in apparent digestibility of lipid and energy.

\section{Proximate analysis of whole body fish}

Proximate analysis of tilapia as affected by FM: CSM ratios, exogenous enzyme protease and their interaction is presented in Table 6. The effect of FM: CSM ratios in diets, it is shown that fish fed the first ratio 2:2 FM: CSM had the highest protein and energy content and the lowest $(p<0.05)$ lipid content while the opposite trend was observed for fish fed the diet with the third ratio (1:2) of FM: CSM) or dry matter and protein contents.

\section{Discussion}

\section{Growth performance and feed utilization}

Cotton seed meal is considered the most cost effective nutritive plant protein by product source, the most commonly used and the most abundant plant byproducts as well as has been tested in numerous fish species, including Sarotherodon mossambicus (Jackson et al., 1982) and Oreochromis niloticus (Yue and Zhou 2008; Soltan et al., 2011a\&b), Ictalurus punctatus (Robinson and Tiersch 1995). The obtained results for all parameters of growth performance in the present study agree with those obtained by Garcia-Abiado et al., (2004), who reported that Nile tilapia fed $25-50 \%$ CSM protein as a replacer of FM showed similar body weight as the control while fish fed 75 and 100\% CSM protein replacement showed a significant decline in body weight. Also, Cai et al., (2011) observed that dietary inclusion of CSM up to a concentration of $400 \mathrm{~g} \mathrm{~kg}^{-1}$ diet don't affected growth performance and feed utilization of crucian carp (Carassius auratus gibelio + Cyprinus carpio $\widehat{\jmath}$ ). Moreover, it has no effects on growth for rainbow trout fed dietary CSM supplementation up to $588 \mathrm{~g} \mathrm{~kg}^{-1}$ diet or complete substitution of FM protein (Lee et al., 2006). No significant differences in survival, growth and feed efficiency were observed in fish fed diets replacing up to $100 \%$ FM by CSM for Black Sea Bass, Centropristis striata and up to $75 \%$ FM by CSM in flounder, Paralichthys lethostigma (Anderson et al., 2016).

Condition factor of fish is essentially a measure of relative muscle to bone growth and the differing growth responses of these tissues to diet treatment may be reflected by changes in condition factor (Ostrowski and Garling, 1988). In an earlier study, Robinson and Daniels (1987) investigated CSM as a partial or complete substitute for soybean meal in 
catfish diets. They reported that fish fed a diet containing CSM to totally replace of all soybean meal had similar condition factor compared to fish fed a soybean meal. Yue and Zhou (2008) indicated that up to $60 \%$ of SBM could be replaced by CSM without adverse effect on growth performance of hybrid tilapia fed the diet highest in CSM had a significantly lower protein efficiency ratio and a significantly higher feed conversion ratio than fish fed the other diets. High survival rate was observed in all dietary treatments, and no significant $(\mathrm{P}>0.05)$ difference among treatments was observed. A 64-day growth trial estimated the ability of three different sources of CSM cotton variety/mutant, two transgenic Ultra-low Gossypol Cottonseed lines, a non-transgenic parental control and a commercial variety, instead of $355 \mathrm{~g}$ $\mathrm{kg}^{-1}$ fishmeal in a diet containing $350 \mathrm{~g} \mathrm{~kg}^{-1}$ crude protein. Juvenile Litopenaeus vannamei. No significant $(\mathrm{P}>0.05)$ differences were found in terms of final weight, survival and feed conversion ratio among treatment Richardson et al., (2016).

\section{Digestibility}

Cheng and Hardy (2002) revealed that rainbow trout fed CSM diets at the $5 \%$ or $10 \%$ inclusion rates were not significantly different compared to fish fed the fish meal control diet in terms of $\mathrm{ADC}(\mathrm{P}>0.05)$, indicating that CSM could be used at the $10 \%$ inclusion rate in rainbow trout feed formulations without adverse effect on growth performance and feed utilization. No significant differences in ADC was observed in fish fed diets replacing up to $100 \%$ FM by CSM for Black Sea Bass, Centropristis striata and up to $75 \%$ FM by CSM in flounder, Paralichthys lethostigma Anderson et al., (2016). The apparent digestibility coefficients (ADC) of dry matter significantly decreased with the increase of dietary CSM level, whereas the ADC of lipid was not affected by dietary treatment for juvenile hybrid tilapia, Oreochromis niloticus $\times$ O. aureus Yue and
Zhou (2008). Similar results were showed in Nile tilapia (El-Saidy and Gaber, 2004), and rainbow trout (Luo et al., 2006). However, the ADC of protein for diets containing CSM with two level 15 and $100 \mathrm{~g} \mathrm{~kg}^{-1}$ was significantly lower than that of the control diet. In contrast, the ADCs of protein for tilapia (Orechromis sp.) decreased when the dietary CSM level increased (Mbahinzireki et al., 2001).

\section{Proximate analysis of whole body fish}

Chemical analysis at the end of a feeding trial is frequently used to determine the influence of feed on fish composition. According to Hepher (1990), endogenous factors (size, sex and stage of life cycle) and exogenous factors (diet composition, feeding frequency, temperature etc.) affect the body composition of fish. It should be noted that within endogenous factors, the composition of the feed is only the factor, which could have influenced the chemical composition of fish, as other endogenous factors were maintained uniform during the study. As CSM in the diet increased protein content of whole fish significantly reduced protein content compared to the control group while the opposite trend was also observed for fat content where the increasing levels of CSM in the diets not significantly increased in fat content of the whole fish. Yildirim et al., (2003) supplemented juvenile channel catfish diets with 0 , $300,600,900,1200$ and $1500 \mathrm{mg}$ gossypol from gossypol-acetic acid and fish fed the experimental diets to satiation twice daily for 12 weeks. They found that Body ash did not differ in fish fid diets containing 0 to $900 \mathrm{mg}$ gossypol/kg but was significantly higher in fish fed higher levels of gossypol. No significant differences in body composition was observed in fish fed diets replacing up to $100 \%$ FM by CSM for Black Sea Bass, Centropristis striata and up to 75\% FM by CSM in flounder, Paralichthys lethostigma Anderson et al., (2016).

Table 4. Feed intake (FI), feed conversion ratio (FCR), protein efficiency ratio (PER) and protein productive value (PPV) for $O$. niloticus fed experimental diets for 90 days.

\begin{tabular}{lcccc}
\hline \multicolumn{1}{c}{ Items } & FI g/fish & FCR & PER & PPV \\
\hline FM : CSM (2:1) & 41.42 & $1.29 \mathrm{~b}$ & 2.59 & $64.80 \mathrm{a}$ \\
FM : CSM (2:2) & 39.93 & $1.32 \mathrm{~b}$ & 2.53 & $63.43 \mathrm{a}$ \\
FM : CSM (1:2) & 39.82 & $1.37 \mathrm{a}$ & 2.44 & $61.03 \mathrm{~b}$ \\
Stander error & 0.721 & 0.044 & 0.078 & 2.16 \\
\hline
\end{tabular}

Means followed by different letters in the same column are significantly different $(\mathrm{P}<0.05)$.

Table 5. Apparent digestibility of dry matter (DM), protein, lipid and energy for O. niloticus fed experimental diets for 90 days.

\begin{tabular}{lcccc}
\hline \multicolumn{1}{c}{ Items } & DM & protein & Lipid & Energy \\
\hline FM : CSM (2:1) & $93.09 \mathrm{~b}$ & $89.75 \mathrm{a}$ & 91.03 & 85.81 \\
FM : CSM (2:2) & $93.85 \mathrm{a}$ & $88.05 \mathrm{~b}$ & 91.11 & 84.85 \\
FM : CSM (1:2) & $93.87 \mathrm{a}$ & $86.87 \mathrm{~b}$ & 90.36 & 84.91 \\
Stander error & 0.560 & 0.348 & 0.354 & 0.529 \\
\hline
\end{tabular}

Means followed by different letters in the same column are significantly different $(\mathrm{P}<0.05)$. 
Table 6. Chemical composition for $O$. niloticus fed experimental diets for 90 days

\begin{tabular}{lcccc}
\hline \multicolumn{1}{c}{ Items } & DM & protein & Lipid & Ash \\
\hline FM : CSM $(2: 1)$ & $26.56 \mathrm{a}$ & $59.70 \mathrm{a}$ & $20.41 \mathrm{a}$ & $13.33 \mathrm{~b}$ \\
FM : CSM $(2: 2)$ & $25.33 \mathrm{~b}$ & $60.52 \mathrm{a}$ & $18.50 \mathrm{~b}$ & $15.17 \mathrm{a}$ \\
FM : CSM $(1: 2)$ & $25.21 \mathrm{~b}$ & $58.37 \mathrm{~b}$ & $20.52 \mathrm{a}$ & $14.96 \mathrm{a}$ \\
Stander error & 1.57 & 1.87 & 1.25 & 0.87 \\
\hline
\end{tabular}

Means followed by different letters in the same column are significantly different $(\mathrm{P}<0.05)$.

\section{References}

Anderson, A.D.; Alam, M.S.; Watanabe, W.O.; Carroll, P.M.; Seaton, P.J.; Wedegaertner, T.C.; and Dowd M.K. 2016. Evaluation of Glandless, Solvent-Extracted and Genetically Modified Low-Gossypol Cottonseed Flour as Alternative Protein Sources in the Diet of Black Sea Bass, Centropristis striata and Southern Flounder, Paralichthys lethostigma. Aquaculture 464:618-628.

AOAC 1995. Association of official analytical chemists. In: Official Methods of Analysis of the Association Official Analytical Chemists (Cunni, P.A. ed.), p. 1298, vol. 1, 16th ed. AOAC International, Arlington, USA.

Becker, K.; and Makkar, H.P.S. 1999. Effects of dietary tannic acid and quebracho tannin on growth performance and metabolic rates of common carp (Cyprinus carpio L.). Aquaculture 175: 327-335.

Bostock, J.; Mcandrew, B.; Richards, R.; Jauncey, K.; Telfer, T.; Lorenzen, K.; Little, D.; Ross, L.; Handisyde, N.; and Gatward, I. 2010. Aquaculture: global status and trends. Philosophical Transactions of the Royal Society B: Biological Sciences 365: 2897-2912.

Boyd, C. E. 1990. Water quality in ponds for aquaculture. Alabama Agricultural Experiment Station, Auburn university. Alabama p 462.

Cai, C.; Li, E.; Ye, Y.; Krogdahl, A.; Jiang, G.; Wang, Y.; and Chen, L. 2011. Effect of dietary graded levels of cottonseed meal and gossypol on growth performance, body composition and health aspects of allogynogenetic silver crucian carp, Carassius auratus gibelio $9 \times$ Cyprinus carpio $\hat{\jmath}$. Aquaculture nutrition 17 (4): 353-360.

Cheng, Z.J.; and Hardy, R. W. 2002. Apparent digestibility coefficients and nutritional value of cottonseed meal for rainbow trout (Oncorhynchus mykiss). Aquaculture 212(1):361-372.

Cho, C.Y.; Hynes, J.D.; Wood, K.R.; and Yoshida, H.K. 1994. Development of highnutrient dense low-pollution diets and prediction of aquaculture wastes using biological approaches. Aquaculture 124: 293-305.

Duncan, D.B. 1955. Multiple range and multiple F tests. Biometrics, 11: 1-42.

El-Saidy, D.M.; and Gaber, M. 2002. Complete Replacement of Fish Meal by Soybean Meal with Dietary L-Lysine Supplementation for Nile
Tilapia Oreochromis niloticus (L.) Fingerlings. Journal of the World Aquaculture Society 33(3): 297-306.

El-Saidy, D.M.; and Gaber, M.M. 2004. Use of cottonseed meal supplemented with iron for detoxification of gossypol as a total replacement of fish meal in Nile tilapia, Oreochromis niloticus (L.) diets. Aquaculture Research 35(9): 859-865.

FAO (Food Agriculture Organization) 2010. The State of World fisheries and Aquaculture 2010. Rome, Italy.

FAO (Food Agriculture Organization) 2014. FAO stat. Retrieved Feb.2014.

Garcia-Abiado, M.A.; Mbahinzireki, G.; Rinchard, J.; Lee, K.J.; and Dabrowski, K. 2004. Effect of diets containing gossypol on blood parameters and spleen structure in tilapia, Oreochromis sp., reared in a recirculating system. Journal of Fish Diseases 27(6):359-368.

Hepher, B. 1990. Ingestion, digestion and absorption of food. In: B. Hepher, (Ed.). Nutrition of Pond Fishes. Academic Press, Cambridge, p 16-63.

Jackson, A.J.; Capper, B.S.; and Matty, A.J. 1982. Evaluation of some plant proteins in complete diets for the tilapia S. mossambicus. Aquaculture 27: 97-109.

Kumar, V.; Makkar, H.P.S.; and Becker, K. 2010. Dietary inclusion of detoxified Jatropha curcas kernel meal: Effects on growth performance and metabolic efficiency in common carp, Cyprinus carpio (Linnaeus). Fish Physiology and Biochemistry 36: 1159-1170.

Lee, K.J.; Rinchard, J.; Dabrowski, K.; Babiak, I.; Ottobre, J.S.; and Christensen, J.E. 2006. Long-term effects of dietary cottonseed meal on growth and reproductive performance of rainbow trout: Three-year study. Animal Feed Science and Technology, 126(1): 93-106.

Li, M.H.; and Robinson, E.H. 2006. Use of cottonseed meal in diets of aquatic animals: a review. North American Journal of Aquaculture 68:14-22

Luo, L.; Xue, M.; Wu, X.; Cai, X.; Cao, H.; and Liang, Y. 2006. Partial or total replacement of fishmeal by solvent-extracted cottonseed meal in diets for juvenile rainbow trout (Oncorhynchus mykiss). Aquaculture Nutrition 12(6): 418-424.

Mbahinzireki, G.B.; Dabrowski, K.; Lee, K.J.; ElSaidy, D.; and Wisner, E.R. 2001. Growth, feed utilization and body composition of tilapia (Oreochromis sp.) fed cottonseed meal-based diets 
in a recirculating system. Aquaculture Nutrition 7(3): 189-200.

Naylor, R.L.; Goldburg, R.J.; Primavera, J.H.; Kautsky, N.; Beveridge, M.C.M.; Clay, J.; Folke, C.; Lubchenco, J.; Mooney, H.; and Troell, M. 2000. Effects of aquaculture on world fish supplies. Nature 405: 1017-1024.

Ostrowski, A.C.; and Garling, J.D.L. 1988. Influences of anabolic hormone treatment and dietary protein: energy ratio on condition and muscle deposition of rainbow trout. The Progressive Fish-Culturist 50(3): 136-140.

Richardson, C. M.; Siccardi, A. J.; Palle, S.R.; Campbell, L.M.; Puckhaber, L.; Stipanovic, R.; D.; and Samocha, T.M. 2016. Evaluation of ultra-low gossypol cottonseed and regular glandless cottonseed meals as dietary protein and lipid sources for Litopenaeus vannamei reared under zero-exchange conditions. Aquaculture Nutrition 22(2): 427-434.

Robinson, E.H.; and Tiersch, T.R. 1995. Effects of long-term feeding of cottonseed meal on growth, testis development, and sperm motility of male channel catfish Ictalurus punctatus brood fish. J. World Aquac. Soc. 26 :426-431.

Robinson, E.H.; and Daniels, W.H. 1987. Substitution of soybean meal with cottonseed meal in pond feeds for channel catfish reared at low densities. Journal of the World Aquaculture Society 18(2): 101-106.

Schneider, O.; Amirkolaie, A.K.; Vera-Cartas, J.; Eding, E.H.; Schrama, J.W.; and Verreth, J.A. 2004. Digestibility, faeces recovery, and related carbon, nitrogen and phosphorus balances of five feed ingredients evaluated as fishmeal alternatives in Nile tilapia, Oreochromis niloticus L. Aquacult. Res. 35: 1370-1379.

Soltan. M.A.; Saudy, A.M.; and Fath El-Bab, A.F. 2011a. Rearing of the Nile tilapia (Oreochromis niloticus) on diets containing cotton seed meal enriched with vitamin E. Egypt. J. Aquat., Biol. And Fish 15 (1): 89-104.

Soltan. M. A.; Fath El-Bab, A.F.; and Saudy, A.M. 2011b. Effect of replacing dietary fish meal by cottonseed meal on growth performance and feed utilization of the Nile tilapia, Oreochromis niloticus. Egypt. J. Aquat., Biol., and Fish. 15(2): 17-33.

Statistical Analysis system 1996. SAS/STAT user Guide Release 6.03 Edition. SAS Institute Inc. Cary, North Carolina, USA.

Tacon, A. G.; Hasan, M.R.; and Metian, M. 2011. Demand and supply of feed ingredients for farmed fish and crustaceans: trends and prospects, FAO Fisheries and Aquaculture Technical Paper, No. 564.

Wee, K.L. 1991. Use of non-conventional feedstuff of plant origin as fish feeds - is it practical and economically feasible? In: S. S. De Silva (Ed.) Fish Nutrition Research in Asia. Proceedings of the Fourth Asian Fish Nutrition Workshop. Asian Fisheries Society Special Publication 5, Asian Fisheries Society, Manila, Philippines.

Yildirim, M.; Lim, C.; Wan, P.J.; and Klesius, P.H. 2003. Growth performance and immune response of channel catfish (Ictalurus puctatus) fed diets containing graded levels of gossypolacetic acid. Aquaculture 219(1):751-768.

Yue, Y.R.; and Zhou, Q.C. 2008. Effect of replacing soybean meal with cottonseed meal on growth, feed utilization, and hematological indexes for juvenile hybrid tilapia, Oreochromis niloticus $\times$ O. aureus. Aquaculture 284: 185-189.

Zhou, Q.C.; Tan, B.P.; Mai, K.S.; and Liu, Y.J. 2004. Apparent digestibility of selected feed ingredients for juvenile cobia Rachycentron canadum. Aquaculture 241: 441-451.

\section{النسبة المثلى لإدخال كسب بذرة القطن كمصدر للبروتين فى علائق أسماك البلطى النيلى}

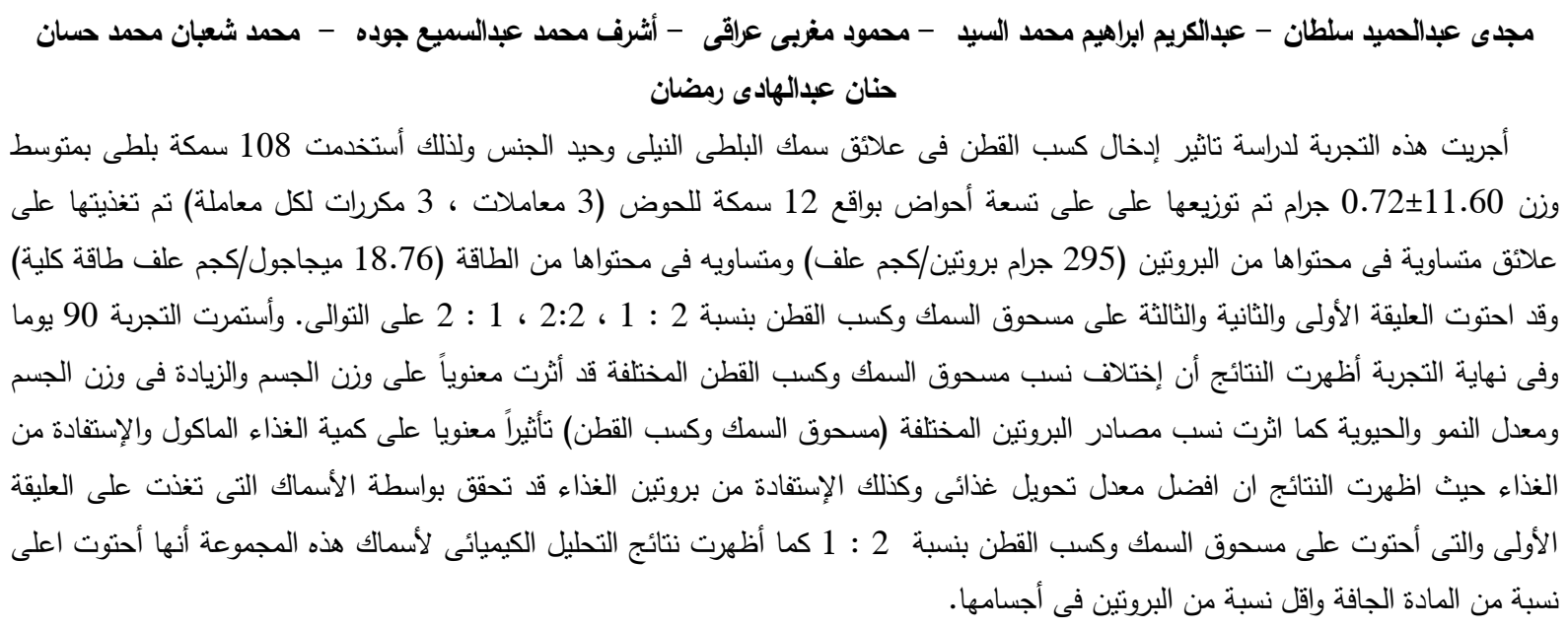

